\title{
OBITUARY: E. J. M. KIRBY
}

With the death of Michael Kirby, at the age of 82 , on 4 February 2011, the world of agricultural science has lost an outstanding experimenter, observer and photographer, and an inspirational colleague and mentor. Persisting in his work on whole plant development, at a time when research funding was increasingly directed towards the molecular, he played a key role in the development of the simulation models that are important tools in the study of climate change. The wheel has turned full circle: his ideas are again considered to be relevant, and his papers are cited in the field of 'phenotyping'.

Michael was born in Henley-on-Thames on 2 October 1928, growing up in Leicestershire, where he attended Wyggeston Grammar School. After a thorough practical grounding in farm work, he studied agriculture at Durham, moving on to Nottingham University School of Agriculture, where he completed a $\mathrm{PhD}$ on the pathology of pasture grasses in 1957. During this work, he was introduced to one of the continuing themes of his later research: charting the embryology of the stem apices of the Gramineae.

With his appointment to the Plant Breeding Institute in Cambridge in the early 1960s, Michael embarked on a long series of studies of the effects of variation in the environment and crop management on the development of wheat and barley plants, making use of the wide range of older and new varieties that were available at the Institute. Over 40 years he published more than 90 scientific papers on cereal physiology and development (a valuable resource, incidentally, when we were writing The Physiology of Crop Yield). This body of work was influential in the transformation of plant development from a qualitative to a quantitative field of study: investigating how the environment influences organ initiation at stem apices, and how this, in turn, determines the numbers of organs formed, as well as the phenology of the plant. His work on the rate and duration of leaf and floral initiation provided new approaches in understanding how crops capture solar radiation.
Although initially sceptical about the usefulness of simulation modelling, he came to see that this was how to test his ideas, in new environments, and with different plant genotypes. He became proactive in working with the leading practitioners, spending time in Texas with Joe Ritchie. In 1981, with his long-term assistant, Margaret Appleyard, Michael published the Cereal Development Guide (second edition in 1984), illustrated with his own photographs, which became the handbook for the testing of the AFRC Wheat Model (The Avalon Survey, published in this journal in 1987).

From the 1970s to the 1990s, when John Monteith was focussing on the efficiency of how plants use radiation, Michael Kirby was developing his ideas of how plants developed their light-absorbing structures. These two great scientists shared a fascination with crops and their growth and development; their complementary legacies survive and continue to receive the scientific accolade of continued relevance long after their insights were made.

After he left Cambridge, Michael spent long periods in the 1980s and 1990s at the University of Western Australia, where his practical approach to crop science was valued. Farmers' groups invited him to teach them how to dissect and evaluate their crops, and he extended his interest to the lupin crop, publishing a guide to its development. In these years, he and his wife Mabel provided memorable hospitality to visiting colleagues. Finally, in his retirement in Suffolk, Michael was continually at work producing the exquisite photographs of insects and churches that featured in his Christmas cards. In a last telephone call, shortly before his death, Michael explained how he was going to modify his wheelchair so as to continue studying the geology of his local quarry. He was a warm and challenging colleague who found it difficult to believe that others did not share his tireless inquisitiveness about the world around him.

ROBERT K. M. H A Y AND JOHN R. PORTER March 2011 